\section{Andy Carolin}

Andy Carolin is a lecturer in the Department of English Studies at the University of South Africa. Email: carolas@unisa.ac.za
Apartheid's Immorality Act and the fiction of heteronormative whiteness

\title{
Apartheid's Immorality Act and the fiction of heteronormative whiteness
}

This article traces both the centrality and fragility of the figure of the heterosexual white male to the moral and ideological core of the apartheid regime. Through a comparative reading of Zakes Mda's The Madonna of Excelsior (2002) and Gerald Kraak's Ice in the Lungs (2006), the article examines how apartheid's Immorality Act functioned as the legislative mechanism to produce and police heteronormative whiteness. The randomness and unpredictability of sexual desire in both historical novels expose the tenuousness of this idealised heteronormative whiteness that lay at the centre of the apartheid project. Situated within the moral panic and political turmoil of the 1970s, the novels identify sex as a powerful lens through which to read the history of apartheid. While Mda's satirical novel focuses on transgressive interracial sexual desire, Kraak's realist text explores same-sex desire and intimacy. My reading of the two novels engages with the political history of apartheid's sexual policing and insists on the inextricable entanglement of its heteronormative and racial supremacist provisions. The traditional ideological centrality of the vulnerable white woman is displaced in the novels by white men whose transgressive sexual desires for black women (in Mda's novel) and other white men (in Kraak's) refuse the certainty and naturalness of heteronormative whiteness. Keywords: apartheid, heteronormativity, historical fiction, Ice in the Lungs (Gerald Kraak), Immorality Act, The Madonna of Excelsior (Zakes Mda), whiteness.

White supremacy is a fleshy ideology; it's very much about bodies. An obsession with skin color is only the most obvious manifestation of this. Put simply, for all its fascination with color, white supremacy is perhaps equally driven by its fascination with sex. (Stokes 133)

\section{Introduction}

As a regime predicated on the separation, oppression, exploitation, and violation of bodies that were not white, apartheid was based on a seemingly monolithic ideology of white supremacy. However, this whiteness was not merely an objective classification of race but rather an active production and policing of idealised ways of being white. Central to this, I argue, is the figure of the heterosexual white male who was simultaneously ubiquitous and invisible in the ideological foundations and priorities of the apartheid regime.

The article traces the centrality of particular configurations of heteronormative whiteness in apartheid ideology through two postapartheid works of historical 
fiction. ${ }^{1}$ Through an analysis of Zakes Mda's The Madonna of Excelsior (2002) and Gerald Kraak's Ice in the Lungs (2006), I examine the intersections of race and sexuality and the significance of the Immorality Act as a legislative mechanism to engineer heteronormative whiteness. In particular, I argue that the two novels evidence both the importance of this race/sexuality nexus to the apartheid project, as well as how sexual desire points to the futility of its underlying ideology. Functioning as a site of transgression and disruption, sex in these novels exposes the instabilities of the Manichean logic on which apartheid ideology was based.

Mda's The Madonna of Excelsior provides a fictional account of the infamous arrest and prosecution of several white men and black women in the town of Excelsior in the then Orange Free State in 1971. They were charged with contravening the miscegenation provisions of the Immorality Act. In Ice in the Lungs, Kraak situates the sexual and romantic relationship between two white men within the antiapartheid movement in Cape Town in 1976. While Kraak's novel has remained largely neglected by scholars, despite winning two major literary awards, significant scholarship has emerged in response to Mda's novel. ${ }^{2}$ However, this scholarship on Mda's text has tended to further separate apartheid's racist and heteronormative mechanisms. In contrast, my comparative reading of the two novels reveals the interconnectedness of racial supremacism and sexual moralism in the production of heteronormative whiteness, which, as I argue, was the ideological foundation of the state.

Despite the texts' similar thematic and historical focuses, they have markedly different styles. The satirical narrative voice in The Madonna of Excelsior contrasts the narrative in Ice in the Lungs which is a decidedly realist novel. Despite these differences, both realism and satire function as productive literary forms of resistance. The distinct narrative modes perform their engagement differently: the satirical communal voice in Mda's novel relies on exaggeration, caricaturing, over-simplification and a carnivalesque tone to "'decentre' South African whites by historicising their dominance and then ridiculing it" (Goodman 63). In contrast, the contemplative realism in Kraak's novel foregrounds nuanced character development, the moral complexities of personal affect, and the deeply intimate and individualised rendering of the entanglement of sex and politics. Despite these stylistic differences, the novels dramatise the ideological constructions of race and sexuality during the moral panic and political turmoil of the 1970s. In doing so, they show how sex-its illicit desires, erotic pleasures, denials, and contingencies-offers a powerful new way of thinking about South African history. The juxtaposition of these two novels resists the tendency to consider the racial and homophobic provisions of the legislation in isolation and demands a reading of the wider project of heteronormative whiteness of which the Immorality Act was an essential part. 


\section{The Immorality Act and the making of heteronormative whiteness}

The first iteration of the Immorality Act came into effect in the late 1920s and prohibited sexual relations between those classified as European and those classified as natives. ${ }^{3}$ This law was amended several times between 1950 and 1988 to intensify restrictions on and penalties for interracial (and later same-sex) physical intimacies. While such white supremacist opposition to miscegenation underscored much of the colonial project, its various codifications by the South African legislature marked intensifications of its segregationist and white supremacist philosophies. ${ }^{4}$ However, the very notion of whiteness on which the apartheid system was based is of course a legally and politically manufactured myth. Kopano Ratele ("Sexuality") points to the extensive workings of the race-making legislative apparatus of the apartheid regime and highlights the way in which it exposes the arbitrariness and constructedness of whiteness as a category. Ratele ("Sexuality") focuses on specific instances in which the Population Registrar, the Race Classification Appeal Board and the Supreme Court conferred or denied whiteness, indeterminately predicated on appearance, descent or lifestyle. This points to the absurdity and arbitrariness of the shifting definitions of whiteness (and race more generally) in which one could be racially reclassified by a mere bureaucratic or judicial stroke of a pen. The Population Registration Act (1950) is identified as a key legislative tool that produced and preserved whiteness (Ratele "Sexuality"; Posel), though Ronit Frenkel (9) writes that this piece of legislation "was amended more than fifteen times as the logistics of an enforced (and bizarre) racial taxonomy had to be continually refined and constructed". While Ratele is concerned with the way in which whiteness as a legal category was made and unmade, he also highlights the links between the Population Registration Act and the miscegenation provisions in the Immorality Act. It is through the Immorality Act that idealised notions of whiteness needed to be produced and policed-legally, symbolically and reproductively—to sustain the racial myths of Otherness and superiority on which apartheid was based. It is the Act's prohibitions on interracial sex (and the centrality of these injunctions in sustaining the fiction of racial purity) that Mda parodies in his novel.

However, such monitoring, which Glen Elder (158) calls "state voyeurism", extended beyond racial eugenics and concerned itself more generally with which bodies were doing what with whom. ${ }^{5}$ The successive statutory amendments to the Immorality Act also shaped legislative restrictions on prostitution, drag performances, displays of same-sex eroticism in public, and even sex toys. The legislative amendment in 1969 relating to same-sex relations between men was precipitated by a highly publicised moral panic about the threats posed by gay men to South African society. ${ }^{6}$ Following the now famous police raid on a house party in Forest Town, Johannesburg, comprising predominantly gay men in the mid-1960s, the state sought to intensify its moralist control of sexual bodies. ${ }^{7}$ While sodomy was already prohibited under the common law, the state insisted that it needed wider powers in 
order to arrest and prosecute offenders. ${ }^{8}$ However, although the final law was less oppressive than had been feared (owing to intense lobbying by civil society), and despite the fact that there were periods of fewer arrests and prosecutions, Edwin Cameron (89-98) notes that homosexuals lived in fear and were turned into "unapprehended felons". Their trepidation was no doubt intensified by the vitriolic political discourses that circulated, such as the address to the House of Assembly in 1967 by Minister of Justice P. C. Pelser in which he insisted on the need for stricter legislation to regulate non-normative sexualities. Minister Pelser (in Retief 99) argued that

history has given us a clear warning and we should not allow ourselves to be deceived into thinking that we may casually dispose of this viper in our midst by regarding it as innocent fun. It is a proven fact that sooner or later homosexual instincts make their effects felt on a community if they are permitted to run riot [...] Therefore we should be on the alert and do what there is to do lest we be saddled later with a problem which will be the utter ruin of our spiritual and moral fibre.

The connection that the apartheid-era minister makes elsewhere in the speech between the fall of the Roman Empire and practices of same-sex sexuality is as myopic as it is fallacious. His reference to the "viper in our midst" situates the transgressive figure of the sexual 'deviant' as an insidious and immense threat to the foundations of the state and society. The fact that "homosexual instincts", according to this minister, risk leading to the "utter ruin of [South Africa's] spiritual and moral fibre" reveals how white heteronormativity was imbricated in the very formation of statehood. Jeremy Martens (224) reminds us that even the initial statutory prohibition on interracial sex was similarly intended to prevent "immoral acts that threatened white civilisation". It is within this context of hysteria and conservative moralism that both interracial sex and sex between men are hyperbolically positioned as threats to white civilisation in general, and the privileged status of Afrikaner nationalism more specifically.

Noting the multiple sites of Otherness on which Afrikaner nationalism depended, Mark Gevisser (31) incisively writes that "Nationalist control over South Africa was consolidated through the construction of bogeymen, and to the black conspiracies, communist conspiracies, English conspiracies, Jewish conspiracies, could now be added the 'queer conspiracy'".

Kobus du Pisani ("Shifting Sexual Morality" 192) similarly notes the manufacture of moral panic through the mobilisation of religious, media and legislative resources-what Gevisser refers to as "the construction of bogeymen" — to "elevate homosexuality to the status of some sort of volksgevaar (threat to the nation)". Thus, interracial or same-sex relationships, like those represented by Mda and Kraak, would be perceived as threats to national order and the ideologies that legitimised apartheid.

Both Mda's and Kraak's historical novels similarly resist the truism that protecting the sexual purity of white women from predatory black men was the symbolic and 
ideological basis of apartheid's moralist controls and interventions. Sandra Swart (80), for instance, in her analysis of a conservative Afrikaner far-right formation, argues that in apartheid ideology, women "serve a rhetorical function-used as metonyms to represent white Afrikaner civilisation. Women are the symbol of that which the [militant Afrikaners] seek to protect." Ratele ("Sexuality" 164) similarly identifies the symbolic place of the white woman as the custodian of moral virtue in need of protection. Tlhalo Raditlhalo (115), for his part, highlights the similarities between white supremacist ideologies in South Africa and the United States and argues that "Afrikaner nationalism, built as it was on racial purity, had also framed Afrikaner women as the epitome of purity, sexual desire, and correct values". This depiction of white womanhood has considerable traction in apartheid-era literature about sexual transgressions. For instance, in Athol Fugard's play Statements After an Arrest Under the Immorality Act (1972), it is the white female character who needs to be 'protected' from the coloured man, despite the consensual nature of their sexual relationship. In other words, the play dramatises the characteristic deployment of the vulnerable white woman as the basis for the state's legislative social controls. Similarly, an interracial love affair in André Brink's Looking on Darkness (1974), which was originally published in Afrikaans as Kennis van die Aand (1973), highlights the fear of the predatory sexuality and violence of a coloured man and foregrounds the vulnerability of a white woman who ultimately dies at his hands. That these representations persist despite Fugard's and Brink's positioning themselves as liberal opponents of apartheid points to the pervasiveness of particular ways of conceptualising the symbolic and sexual vulnerability of the white female body.

In contrast to this, however, both Ice in the Lungs and The Madonna of Excelsior resist locating the vulnerable white woman as the interpretive figure who underscores apartheid's sexual policing and instead reveal the ubiquity of the heterosexual, white male in the ideology of the regime. In this regard, Elder (160) points out that it was an "anxiety about white male bodies" that drove the parliamentary investigation into non-normative sexualities. This investigation was based on the supposed existence of a "normative heterosexual masculinity" that was under threat (Elder 160). Women's sexuality, according to Elder (156), was seen merely as a site of reproduction and thus there was very little perceived threat posed by lesbian sexual activity. Even the limited legislative interest in lesbian women was predicated on the ontology of heterosexual men, as Retief (103) intimates: “The MPs [members of parliament] were rather worried about the sizes, shapes and attributes of the different kinds of 'dilders' used by lesbians" - with one MP enquiring whether "this instrument [is] of normal or abnormal size". Retief (103) observes that in addition to the general exclusion of lesbian sexuality from the moral oversight of the state, black men who had sex with other black men were also generally overlooked. The well-documented sexual relationships between black men in the mining compounds (Moodie)_ironically 
created through the exploitative social engineering of the same regime-was not of major concern to the sexual moralists (Elder 160; Du Pisani "Shifting Sexual Morality" 189; Gevisser 18). This further illustrates that it was the intersecting racial and gendered privilege and bodily integrity of heterosexual white men that shaped what Retief (99) calls "[a]partheid's war on sexual dissidence".

Reflecting further on the ideological centrality of heteronormative whiteness in South African history, Elder (162) writes that "what white male homosexuality threatens is a patriarchal and racial order that shaped interlocking structures that provided many white Afrikaner males access to power during apartheid". This figure of an essentialised white heterosexual male is the product of cultural programming which drew on Afrikaner Christian Nationalism. ${ }^{9}$ Du Pisani ("Puritanism transformed" 158) argues that

[h] egemonic Afrikaner masculinity was essentially puritan in nature. It took an unyielding Protestant view based on 'pure' New Testament principles, and rigid austerity and strictness in conduct and morals. The puritan basis of Afrikaner masculine ideals stemmed from the strong influence of religion in Afrikaner society and the close synergy between religious, political and cultural leadership in Afrikanerdom.

In The Madonna of Excelsior, Mda (29-30) finds the roots of this view in the words of former Prime Minister J. G. Strydom:

As a Calvinist people we Afrikaners have, in accordance with our faith in the Word of God, developed a policy condemning all equality and mongrelisation between White and Black. God's Word teaches us, after all, that He willed into being separate nations, colours and languages. (Italics in original)

Du Pusani ("Puritanism transformed" 159) goes on to list "heterosexuality and political conservatism" as two specific requirements for hegemonic masculinity. Though Michael Kimmel (338) acknowledges the performative and contextual nature of gender, he suggests that " $[\mathrm{t}]$ ypically, each nation constructs at least one model of masculinity against which each man measures himself and against which other men measure him". Hence, given the instabilities of whiteness as a "contingent and situated identity" (Nuttall 135), and the contested nature of white hegemonic masculinities that characterised the colonial and apartheid periods, idealised configurations of (heteronormative) whiteness need to be actively produced and policed. Gevisser (30-31) notes that in order to "consolidat[e] Afrikaner 'Christian National' control over the country, [the South African government had to] expel from the laager anything that was deemed threatening to white civilisation" which included both interracial and same-sex sexual relationships. As my reading of the texts will show, the contraventions of the Immorality Act in Kraak's and Mda's novels situate the body as a site of legal transgression and symbolic subversion. 


\section{The Madonna of Excelsior}

Despite the multiple sexual relationships that are represented in The Madonna of Excelsior, the novel focuses particularly on the experiences and perspectives of Niki, a black woman who lives in a racially segregated township in Excelsior. Niki becomes part of a group of black women in the town who engages in sexual activities with prominent white men. The extent to which this sex is consensual is sometimes uncertain and may be described at different points as forced, coerced, transactional or voluntary. Niki's rape earlier in the novel is located within a broader culture of violence and violation in which black female bodies are marked as fodder for the production of a racialised patriarchy. Then, perhaps not unexpectedly, Niki and some of the other black women who participate in these sexual activities become pregnant and they ultimately give birth to what would have been classified as coloured children. These children form the evidentiary basis on which the state pursues charges of contravening the Immorality Act. As evidence of the interracial sex, the children make the community's claims of an unblemished whiteness untenable. Reflecting on Mda's novel, Ralph Goodman (63) insists that "[t]he Immorality Act was an attempt at colonial eugenics, appearing to even-handedly prohibit any mingling of race, but covertly constructing black South Africans in particular as so degenerate that their genes had to be contained, lest they damage the fabric of society".

Thus, uncontaminated whiteness is seen as essential in preserving the Manichean divisions on which apartheid ideology relied. There is a significant tension that is staged in the novel between interracial sexual desire as an exceptional anomaly that needs to be excised on the one hand, and interracial sex that is widespread and indeed constitutive of cultures of Afrikaner patriarchy on the other. In his reading of the novel, Goodman (63) indicates just "how crucial it was to the state to maintain the [racial] binary system it had established, attempting to naturalise it by labelling any breach of the system as abhorrent".

The ironic narrative voice teases out this tension between desire as an aberration and desire as natural by highlighting the pervasiveness of this lust-and the absurdity of its prohibition-in the following extract:

In various platteland towns Afrikaner magistrates were sitting at their benches, listening to salacious details, and concealing painful erections under their black magisterial gowns. Afrikaners prosecuting fellow Afrikaners with cannibalistic zeal. Afrikaners sending fellow Afrikaners to serve terms of imprisonment. All because of black body parts.

Young Afrikaner boys were eager to taste what their fathers were eating on the sly. They went out on hunting expeditions for what they called swart poes. (Mda 94)

So, beneath the veneer of an ostensibly perfect whiteness lurk illicit desires that need to be concealed. Mda's comic satire depicts and then ridicules the extent of 
interracial sexual desire-staging itself here as "painful erections under their black magisterial gowns". This points to the hypocrisy on which the state's moralist regulation of sexuality depended. Sex as an expression of power is reinforced here by the invocation of imagery of hunting and devouring to depict the fetishised desire that is seemingly both constitutive of and an anathema to Afrikaner masculinity. The significance of interracial desire in the ontological and sexual constitution of white Afrikaner men is unpacked with greater specificity earlier in the novel. The reader learns about the activities of a clandestine sexual orgy grouping controlled by white men in the community which meets regularly for prohibited sexual encounters. The passionate and pleasurable "romps on the hay" (Mda 55) are described as "a cacophony of moans [and] howls" (Mda 55). The heightened exoticised desire for black women is evidenced when one of the peripheral black characters notes that "[w] hite men have always loved us. They say we are more beautiful than their own wives. We are more devastating in the blankets" (Mda 62). Ratele ("Apartheid" 302) warns in this respect against overlooking "racist sexualisation" or "[s]kin fetishisation" in which Othered bodies become objects of desire because of (rather than despite) their Otherness. What makes the transgressions even more significant is the fact that the narrative centres on a group of prominent white men-situated within what Swart (78) calls "the sanctuary of white male privilege" — many of whom held positions in the legal, political or religious orders that legitimised or mandated the Immorality Act. The narrator notes that "the white accused [in the trial] include the secretary of the local branch of the National Party and some of the wealthiest farmers in the district" (Mda 72), the former mayor, a police officer, and the church minister who, according to the unnamed narrator, "preached obedience to His laws [...] against adultery and miscegenation" (Mda 75). Klein-Jan Lombard, a police officer who has previously had sex with black women himself (Mda 78), even volunteers to assist in the prosecution of his own father, thereby performing the role of defender of the volk. The dissonance between sexual desire and political convictions (and the extent to which interracial desire is wilfully blind to these convictions) reveals the futility of sexual and moral policing and the inevitable impossibility of separated racial taxonomies. ${ }^{10}$

In broader terms, Mda's novel complicates dominant ways in which racial and gendered power is rehearsed and performed in colonial and white supremacist contexts. The text revises the racial scripts of sexual predator, seductress, and victim, and interrogates notions of agency more generally. Of interest here is Ruth Frankenberg's (11) trope-ic "cast of characters": "White Woman, White Man, Man of Color, and Woman of Color". Although she draws on particularly American discourses and representations of the relationship between these gendered and racialised tropes, they resonate equally in South Africa during the apartheid period. Frankenberg (11-2) writes that 
White Woman is frail, vulnerable, delicate, sexually pure but at times easily led 'astray'. White Man is strong, dominant, arbiter of truth, and self-designated protector of white womenkind, defender of the nation/territory (and here defense of the nation and its honor often entails defending White Woman's racial chastity). Man of Color [...] is sexually rapacious, sometimes seductive, usually predatory, especially toward White Woman; it is he, in fact, from whom White Woman must be protected by White Man. And, finally, Woman of Color [...] is also sexually eager, seductress, willing and able consort, especially for the White Man of this tropological family....

This "cast of characters" is a useful resource against which the novel can be read. In this text, the black male predator is replaced by white sexual predators; it is black women in need of protection from the lecherous sexual advances of white men; white women are forced to the periphery of relevance; and rather than being defenders of the nation, white men's uncontrolled sexual desires challenge the very separateness and racial purity on which the white Afrikaner nation has been constituted. In addition, the black women are not, in most cases, positioned as seductresses but rather as victims of sexual assault and exploitation. Using satire, Mda confronts the supposed corrupting influence of the black female seductress throughout the novel, where the cohesion of the Afrikaner identity-implicitly conservative, white, male and heterosexual-is said to be under threat by supposedly hypersexualised black women. ${ }^{11}$ This irony is revealed by the unnamed communal narrative voice when it accounts for Reverend Bornman's observation that ${ }^{12}$

[t]he devil had sent black women to tempt him and to move him away from the path of righteousness. The devil had always used the black female to tempt the Afrikaner. It was a battle that was raging within individual Afrikaner men. A battle between lust and loathing. A battle that the Afrikaner must win. The devil made the Afrikaner to covertly covet the black woman while publicly detesting her. (Mda 87)

The character's exaggeration and outsourcing of moral culpability and agency satirises the hypocrisy that characterised the Dutch Reformed Church and other cultural institutions during apartheid. Of significance here is not so much that interracial desire is identified as a threat to an individual, but rather that it is a structuring subtext to hegemonic Afrikaner masculinity more generally. Desire for black women is again seen simultaneously as definitive of and antithetical to particular configurations of the Afrikaner body politic. Similarly, this suggestion that it was in fact the spiritual purity and morality of white men that were under threat by interracial sexual desire-over which, it was insisted, they had little agency-is echoed by the way in which the novel begins and ends. The opening line of the novel_- All these things flow from the sins of our mothers" (Mda 1) - is echoed in the final line of the text when the narrator says "from the sins of our mothers all these things 
flow" (Mda 268). Mda's ironic framing of the narrative ridicules the oft-repeated suggestion that the responsibility for the illicit sexual acts can be projected onto the hypersexual black women and that white men were mere victims of these sins. The narrative voice ironically reflects that "[ $t]$ he devil was on the loose in the Free State platteland. Grabbing upstanding volk by their genitalia and dragging them along the path strewn with the body parts of black women" (Mda 89). In addition to the dehumanisation suggested by black women's dislocated body parts, the hyperbolic narrator also exposes the absurdities and disavowal of agency often used to excuse interracial desire in white supremacist contexts. Particularly relevant here is Goodman's (67) assertion that much of the text is characterised by "an exaggerated air of innocence which immediately undermines itself and declares that its intentions are subversive". Furthermore, Mda (89) writes that "wily as Lucifer might be, he was not going to succeed in his designs to consign the volk to eternal damnation". The importance of idealised ways of being white is clear here, reinforcing the need to expel interracial sexual desire. The shifting meaning of the word volk in Mda's text-referring both to people and then to the nation-highlights the imbrication of the individual or family in the broader discourse of nationalism. This confirms Swart's (80) insistence that "[ $\mathrm{t}]$ he white Afrikaans-speaking heterosexual family unit is seen as the minima of civilisation".

The trope of white men as victims of sexual desire in need of protection from nefarious sexual advances, an idea which Mda satirises, is evident in earlier fiction on the Immorality Act. In Alan Paton's famous Too Late the Phalarope (1955), for example, the protagonist is a white police officer who is tormented and disgusted by his feelings of lust for black women. He describes his sexual desires as a "mad sickness" that would "strike [him] down if it could" (Paton 46, italics in original). Significantly, the black woman in Paton's novel with whom the police officer has sex, and whom Raditlhalo (116) calls a "temptress" in his reading of the text, exposes the illicit affair to his superiors, but is ultimately denied narrative agency. Rather, she is reduced to a mere conduit for the political and ontological downfall that results from the protagonist's torturous desires. In contrast to this, Niki in Mda's novel responds to the regular sexual advances made by different men in a more judicious way. As a young woman she first has transactional and forced intercourse with Johannes Smit and later chooses to have sex exclusively with Stephanus Cronje, the owner of the butchery where she works. On hearing that Niki may have been intimate with another one of the farmers, Stephanus Cronje clearly articulates his desires when he "frantically" states: "Dammit, Niki [...] it is me you should be doing things with, not that Johannes Smit" (Mda 50). Johannes Smit's libidinal investment is also made clear when the narrator notes that he "died of desire every time he thought of her. Especially when he imagined all the things she must have done with Stephanus Cronje" (Mda 53). After being criticised for his "unsportsmanly" refusal to share 
Niki with the other white men, Cronje remarks "with a tinge of boastfulness in his voice" that if the other men in the orgy "banish us from here, Niki, we'll just do our thing in the sunflower fields" (Mda 53). The competition that ensues between these two white men for the beautiful Niki suggests an inversion of the register in which race and desire have been represented. As a rule, the dominant representational mode dictates that "[b]lack female bodies are sites of ungovernable lasciviousness [while white] female bodies become sexual territory to be displayed, fought over, and protected" (Stokes 133). Niki's initial reticence contradicts the stereotypically uncontrollable lust attributed to black women, while at the same time her black body displaces the centrality of white women in the economy of sexual exchange, who, incidentally, become marked by humiliation and inaction in the novel. While Niki does not seduce the white men, in fact resisting their advances a number of times, her participation in the sex is unexpectedly informed by a deeply articulated sexual agency. The narrative voice asserts that of all the women involved in the interracial sex orgies, Niki "seemed to be the only one of the women who had full awareness of the power packed into her body. And she was using it consciously to get what she wanted" (Mda 53). For Niki, sexual intercourse is a complex entanglement of pleasure and power, sensual "ecstasy" (Mda 56) and revenge. Though her motivations and consent in her earlier encounters with Johannes Smit are either absent or uncertain, the narrative focalisation of Niki makes her reasons for agreeing to have sex with Stephanus Cronje very clear. After being falsely accused of theft by Madam Cornelia Cronje and forced to strip down fully to be searched, "anger was slowly simmering in Niki. A storm was brewing. [...] Behind her serene demeanour she hid dark motives of vengeance. Woman to woman" (Mda 42). During sex with Stephanus Cronje, Niki "did not see a boss or a lover. She saw Madam Cornelia's husband, with the emphasis on Madam. And she had him entirely in her power" (Mda 50). The "emphasis on Madam" also subverts Frankenberg's trope-ic cast of characters by pointing to the political agency and complicity of White Woman in sustaining the victimisation and oppression of Black Woman. Niki's erotic agency and the disassembled cast of characters invert stereotypical power relations and undermine the mythologies of racial purity and sexual moralism that were integral to heteronormative whiteness.

\section{Ice in the Lungs}

Kraak's novel similarly interrogates sex as a site of power and transgression as it explores the experiences of its primary narrator Matt in the antiapartheid movement in Cape Town in 1976. The narrative centres on his romantic and sexual involvement with Paul, an antiapartheid unionist and activist. However, as Paul becomes increasingly immersed in politics, Matt's exploration of sex in the city exposes some unexpected overlaps and political contradictions. The initial intensity in the rela- 
tionship between Matt and Paul is undeniable and offers a celebratory disavowal of heteronormative whiteness. The obvious sexual passion between the two men occludes the moral oversight of the state. Following Matt's acknowledgement that there was the "painful, hot-blooded knowledge that [he] wanted Paul" (Kraak 112), he describes kissing him:

[Paul] tugged me close to his tight body and put his lips into the crease of my neck, biting the soft flesh there. Then he put his hands into my hair, inclined my head backwards, and covered my mouth with his. I entered into a heady communion, a silken comprehension of the membranes of his cheeks, the smooth ridges of his teeth-a merging of sensations that came in waves of giddy sensation from my abdomen, groin, and the back of my head. (119)

The celebratory sensuality and intimacy of Matt's narration-differing sharply from the satirical mode of Mda's text-reveals sincerely the desire between the two men. Kraak parodies the language of religion when he celebrates same-sex intimacy as "a heady communion". By doing so, Kraak challenges the ubiquity of religion in political and social discourse (and in the production and insistence on heteronormativity). The affirming and celebratory eroticism that characterises several depictions of same-sex intimacy in the novel emphasises the ethical bankruptcy of both homophobia and the Immorality Act's policing of desire. ${ }^{13}$

While high levels of homophobia existed within white society, it is indeed the apartheid government that is positioned as the custodian of heteronormative whiteness. In fact, insistences on conservative moralism appear to be inextricably bound to the defence of the state. This ideological convergence is made clear when police officers vandalise the outside wall of Paul's flat: he wakes up to find graffiti painted on his wall with the words "Paul Hudson, moffie, holnaaier, kaffirboetie, Kommunis, woon hier". ${ }^{14}$ (Kraak 243) Evidencing the intersections of white supremacy, homophobia and political conservativism, this graffiti marks Paul as Other, not only to the state itself but also to the broader project of heteronormative whiteness. That the graphic evidence of Paul's sexual dissidence and his progressive political attitudes appear on the wall alongside the infamous symbol of communism, the hammer and sickle, frames as treasonous his transgression of the codes of heteronormative whiteness. In other words, the ideologically rigid Christian sexual moralism is represented through the police actions as being inextricably entangled with the state's broader propaganda campaigns.

The novel further identifies the apartheid-era military as one of the most significant sites for the (re)production of racial and gendered power. A friend and housemate of the protagonist, Oliver, who has escaped from military conscription, describes his experiences in the South African Defence Force (SADF) and states that " $[\mathrm{t}]$ heir entire purpose was to break down your resistance, brainwash you and recon- 
stitute you as malleable putty_fodder for the war machine" (Kraak 30). Central to this was the exclusion of those gendered identities that were potentially disruptive to the institutional culture that the military sought to inculcate. Oliver recalls that undesirable men-including "drug addicts, thieves, insubordinates like himself [and] homosexuals who'd been caught in the act" (Kraak 80-1) - were removed from active military bases and were sent to detention barracks or even psychiatric facilities. The torture and shock therapy that ensued for those who failed to comply with the normative ideals of Afrikaner Christian Nationalism (Kraak 80-1) similarly reveal the extent to which the state machinery participated in the production and preservation of idealised ways of being white.

The contemplative realism of Kraak's text gives further insight into the subtle complexities of the protagonist's experience of sexuality in the city, his sexual and emotional relationships, and the moral imperatives of antiapartheid activism. The affect that is layered in this narrative mode captures the intersecting complexities of political solidarity, lust, love, and betrayal. Later in the novel, after having a fight with Paul, Matt is "driven by sexual need, by revenge for weeks of emotional deprivation" (Kraak 262) to a gay bar in Cape Town's Long Street. This bar is one of a number of spaces of eroticised masculinity that exist in defiance of apartheid's moral oversight. The novel describes several sites for casual and often anonymous same-sex sexual encounters that exist in urban gay communities in Cape Town, including "[p]arks, the beachfront, sometimes bars" (Kraak 159). Furthermore, Dawie, who Matt meets at the gay club, tells him that "Xanadu is where you come if you like big, well-built men who work their bodies. But you could go to the Blue Mountain Lodge -it's full of moffies and drag queens" (Kraak 265-6). The sheer construction of these clubs as sexualised spaces is in itself a political act. Vasu Reddy (69) correctly notes that given the relevant legislative provisions "gay clubs and gay restaurants were theoretically operating illegally" at the time in which Kraak's novel is set. In a similar vein, Peter Galli and Luis Rafael (137-8) note that places that allowed for physical intimacy between men during apartheid provided a brief reprieve from the moralist interference by the homophobic and racist state apparatus. Thus, although not political in the traditional sense, these clubs were themselves sites of resistance to heteronormativity. Interestingly, hiding in plain sight, these clubs straddled a space of hypervisible invisibility and were simultaneously constitutive and transgressive of the ideological landscape of the apartheid project. Dawie goes on to foreground his personal experiences: "'I'm a regular here,' he smiled. 'I come here most Fridays and Saturdays. It's a combination of people I've gotten to know, to have a drink with and dance with—and maybe have sex with. Men come here to pick up other men. Like there in the corner'" (Kraak 265).

Matt appears to embrace this culture willingly when he acquiesces to Dawie's offer to have sex with him, noting with visceral abandon that "lust began to pulse 
up through [him]" (Kraak 266). Matt then goes home with Dawie and has sex with him several times during the weekend. Similar to what Mda does in The Madonna of Excelsior in his descriptions of the male transgressors, Kraak deploys the trope of the stereotypically conservative Afrikaans-speaking South African male in his depiction of Dawie. Dawie, we are told, is passionate about rugby and speaks with "flattened vowels [that] suggested he had grown up on the platteland" (Kraak 264). The extent to which Dawie complies with expectations of nationalist hypermasculinity is evidenced further by the magazines that he reads, which contain glorified accounts of the border war, photographs of dead SWAPO guerrillas "laid out in the dust of some arid village", and stories about game hunting (Kraak 270). Dawie is depicted in this initial encounter as presumably supportive of the apartheid regime and its characteristic hypermasculinity, a point later confirmed when Matt realises that Dawie is a police officer who is involved in the subsequent criminal case against Paul (Kraak 294). Much like the prominent political and cultural leaders in Mda's novel, and the protagonist in Paton's Too Late the Phalarope, Dawie transgresses the very laws that he is tasked to enforce. In all other respects a traditional Afrikaner male and defender of the volk, Dawie exposes how sexual desire evidences the hollowness of the moral and cultural codes of whiteness. His sexual desire, depicted as normal and natural in the text, challenges the apparent obviousness with which moral policing became hinged to racial superiority.

The fact that Matt's sexual liaisons with other men constitute acts of transgression and resistance to particular idealised ways of being white is explained when Oliver later reflects: "[w]e hold views that are practically treasonable. Do you think your socialist worker republic is something for which [white people] would have regard? They'd rather have you behind bars. So what does it matter adding to the cauldron of your sins that you have sex with men?" (Kraak 139)

Oliver not only reads same-sex sexuality through the lens of sedition but he also observes the entanglement of white supremacy with homophobia. He suggests that conservative white South Africans who are complicit in apartheid will automatically abhor same-sex intimacies between men. However, this assumption is problematised through Matt's highly erotic sexual liaisons with Dawie. Hence Kraak's text resists any reductive reading of how agents and beneficiaries of apartheid related to issues of same-sex desire, which in turn refutes attempts to construct a normalised citizenship predicated on erotic conformity and control. Dawie therefore functions in the novel to destabilise monolithic representations of how conservative white South Africans engage with issues of same-sex desire and to force fractures into the seeming solidity of apartheid ideology.

Destabilising the Manichean logic of the apartheid regime, sexual desire is therefore shown to be a subversive political force. Matt's sexual activity with Paul, an antiapartheid activist, and Dawie, the police officer who defends the regime, reveals 
that same-sex desire traverses different political ideologies and exposes unexpected networks of transgression. Significantly, unlike the political and cultural elite in The Madonna of Excelsior, Dawie's sexual offences do not lead to his downfall. In fact, unlike the community of Excelsior, the transgression remains cloaked in secrecy and the structures of whiteness remain unchanged. In Kraak's novel, rather, same-sex desire and intimacy is consistently positioned as an affirming and pleasurable experience. Pointing simultaneously towards the centrality of the heteronormative white male and the inherent instability of this specific figure, Dawie challenges traditional binaries of oppressor/oppressed, law/transgression, and moral/immoral.

Kraak's novel itself confronts the interconnectedness of the racial and sexual provisions of the Immorality Act. Significantly, Matt's illegal sexual relationship with Paul is juxtaposed with the illegal relationship that his female housemate, Pru, is having with Temba, a black antiapartheid activist. The illegality of Matt and Paul's intimacies is grounded in its same-sex nature, whereas Pru and Temba's relationship is illegal because it is interracial. The textual proximity of these sexual encounters emphasises the links between race and sexuality during apartheid. The protagonist recalls that he looked into an open window and "on the pillow, unmistakably, the dreadlocks of a sleeping head. It's Temba, I suddenly realised. Christ, Temba, the man from The Kalamata. I knew then he was Pru's lover. And now, as Pru and I walked to our lecture, I thought wistfully about the equally secret tryst between Paul and myself" (Kraak 126).

Kraak makes it clear that it is the same piece of legislation-the Immorality Act-that proscribes both same-sex (242) and interracial (196) sexual intercourse. By juxtaposing Matt's and Pru's sexual affairs, Kraak's novel engages with the changing social fabric of society, especially insofar as it relates to the legitimacy of private sexual intimacies. Kraak's novel stages a conversation between the racial and heteronormative components of the state's system of moralist oversight and control, not only drawing attention to their similarly articulated transgressions, but also further highlighting the complex entanglements of erotic agency, political ideology, and identity. This juxtaposition also contests the recurring claims from within the antiapartheid movement that the oppression of homosexuals was not a basis for political activism, ${ }^{15}$ gesturing potentially to the complex connections between racism and heteronormativity in the antiapartheid movement as well.

\section{Conclusion}

Kraak's and Mda's novels are significant as works of historical fiction as they constitute alternative reflections on the apartheid past, going some way in assuaging Retief's concerns about the elision of histories of apartheid's sexual prohibitions. ${ }^{16}$ The texts speak to Retief's (100) observation that in most historical discourses, "[m]oral policing is regarded simply as another part of South African law enforcement-as normal and 
unremarkable as speed traps or parking fines". Not only do Mda's and Kraak's novels reflect the discursive and legal making and unmaking of heteronormative whiteness in a white supremacist context, but they also offer new ways of reading apartheid history more generally. In drawing attention to how certain forms of sexual desire were always already subversive transgressions of apartheid ideology, the novels trace in particular how white men, many of whom were employed by the state, pursued illicit sex with either black women or other men. A comparative reading of the two texts shows that racism and heteronormativity (as mutually supporting operations) are regulated through the Immorality Act as the state prioritised social control, racial purity, and erotic normativity. Hence, these two novels, each in their own way, foreground the desires and sexual agency of those Othered by apartheid's sexual moralism, including black women, gay men and male Afrikaner agents of the state. This further resists the truism that white women lay at the heart of apartheid's moral policing. As a site of transgression, then, sexual desire disarticulates and renders unstable the figure of the idealised white, heterosexual man for whom the apartheid regime was structured.

\section{Notes}

1. Heteronormativity, a term originally coined by Michael Warner, refers to the cultural and social forces that position heterosexuality and traditional gender identities as normal. The term is largely synonymous with what Adrienne Rich calls "compulsory heterosexuality".

2. See, for example, Courau, Crous, Fincham, Flockemann, Goodman, Raditlhalo, and Zulu.

3. See Martens for a detailed discussion of the 1927 Act.

4. See Posel for a fuller history of the 'making' of race in South Africa. Similarly, see Green, Sonn, and Matsebula for further discussion of the discourses of whiteness during the apartheid and postapartheid periods.

5. See Arseneault's analysis of John Greyson's film Proteus for a comparable discussion of the policing of race, masculinity and desire in South Africa in the eighteenth-century.

6. Despite the obvious limitations of using identity-based nomenclatures such as gay, lesbian and homosexual to describe same-sex intimacies and relationships, this is the language that is used by Kraak throughout the novel. Though Gevisser and Cameron (3) note with concern that "[w]hat has passed for the 'gay experience' has often been that of white, middle-class, urban men," it is in fact this very demographic that Kraak focuses on in his novel.

7. For a more detailed historical analysis of the significance of this police raid, see Gevisser, Retief, and Elder.

8. While the term 'sodomy' is often used ambiguously, it is the word that was used in common law prohibitions of same-sex physical acts, usually denoting anal sex though not always limited to this.

9. See Du Pisani ("Puritanism transformed") and Swart for analyses of the shifts in Afrikaner nationalism during the latter half of the twentieth century.

10. While the sexual exploitation in the novel should not unproblematically be read as an emancipatory unmaking of apartheid (lest one yet again appropriate the black female body for ideological purposes), the interracial desire that it evidences points to the inevitable failure of the idealised persona of the heteronormative white male that figured so centrally in the machinations of the regime.

11. Courau argues that while stereotypes of Afrikaners are used and satirised in the novel, a detailed Afrikaner cultural life is also depicted. Courau (115) states that the representation of Afrikaners in the novel is "a multifaceted negotiation of historical and cultural fact".

12. See "The collective voice in The Madonna of Excelsior: narrating transformative possibilities" by N. S. Zulu for a fuller discussion of the narrative perspective in the novel.

13. For example, Matt refers enthusiastically to being "fucked against the trunk of a fallen tree" (Kraak 161) 
and "thudd[ing] into [another man], drawing from him ever deeper tenors of response. I came inside him, in a sensation so intense that the room came back to me in waves of renewed consciousness" (Kraak 267).

14. This is translated by Kraak (243) in a footnote to the text which reads: "Paul Hudson, queer, butt-fucker, nigger lover, Communist, lives here".

15. See Toms, Nkoli, and Kleinbooi for more on the intersections of homosexuality and the struggle against apartheid.

16. See Carolin for my earlier discussion of the relationship between history and fiction in relation to Kraak's novel.

\section{Works Cited}

Arseneault, Jesse. "Queer desire and the men of the nation: Reading race, masculinity, and South African national identity in John Greyson's Proteus." Safundi 14.1 (2013): 37-58.

Brink, André. Looking on Darkness. London: W.H. Allen, 1974.

Cameron, Edwin. "'Unapprehended felons': Gays and lesbians and the law in South Africa." Defiant Desire: Gay and Lesbian Lives in South Africa. Ed. Mark Gevisser and Edwin Cameron. Braamfontein: Ravan Press, 1994. 89-98.

Carolin, Andy. "A novel archive of intimacy: Sex and the struggle in Gerald Kraak's Ice in the Lungs." Journal of Literary Studies 31.3 (2015): 49-66.

Courau, Rogier. "Reading transnational histories." Scrutiny2 10.2 (2005): 103-15.

Crous, Marius. "'A battle between lust and loathing': The interplay between masculinity and femininity in Zakes Mda's The Madonna of Excelsior". Tydskrif vir Letterkunde 47.1 (2010): 79-94.

Du Pisani, Kobus. "Puritanism transformed: Afrikaner masculinities in the apartheid and post-apartheid period." Changing Men in Southern Africa. Ed. Robert Morrell. Pietermaritzburg: U of Natal P, 2001. 157-75.

. "Shifting sexual morality? Changing views on homosexuality in Afrikaner society during the 1960s." Historia 57.2 (2012): 182-221.

Elder, Glen. S. "The South African body politic: Space, race and heterosexuality." Places through the Body. Eds. H. Nast and S. Pile. London: Routledge, 1998. 153-64.

Fincham, Gail. Dance of Life: The Novels of Zakes Mda in Post-apartheid South Africa. Cape Town: Juta and Company, 2011.

Flockemann, Miki. "Traumas and transformations: Fictions which play with what 'They Say', by Zakes Mda and Lindsey Collen". Journal of Literary Studies 20.3-4 (2004): 248-64.

Frankenberg, Ruth. "Introduction: Local whitenesses, localizing whiteness." Displacing Whiteness: Essays in Social and Cultural Criticism. Ed. Ruth Frankenberg. Durham: Duke U P, 1997. 1-33.

Frenkel, Ronit. Reconsiderations: South African Indian Fiction and the Making of Race in Postcolonial Culture. Pretoria: Unisa Press, 2010.

Fugard, Athol. Interior Plays. New York: OUP, 2000.

Galli, Peter and Luis Rafael. "Johannesburg's 'Health Clubs': Places of erotic languor or prison-houses of desire?" Defiant Desire: Gay and Lesbian Lives in South Africa. Ed. Mark Gevisser and Edwin Cameron. Braamfontein: Ravan Press, 1994: 134-9.

Gevisser, Mark. "A different fight for freedom: A history of South African Lesbian and Gay Organisationthe 1950s to the 1990s." Defiant Desire: Gay and Lesbian Lives in South Africa. Ed. Mark Gevisser and Edwin Cameron. Braamfontein: Ravan Press, 1994. 14-86.

Green, Meredith, Christopher Sonn and Jabulane Matsebula. "Reviewing whiteness: Theory, research, and possibilities." South African Journal of Psychology 37.3 (2007): 389-419.

Goodman, Ralph. "De-scribing the centre: Satiric and postcolonial strategies in the Madonna of Excelsior." Journal of Literary Studies 20.1/2 (2004): 62-70.

Kimmel, Michael. "Afterword." Changing Men in Southern Africa. Ed. Robert Morrell. Pietermaritzburg: U of Natal P, 2001. 337-40.

Kleinbooi, Hein. "Identity crossfires: On being a black gay student activist." Defiant Desire: Gay and Lesbian Lives in South Africa. Ed. Mark Gevisser and Edwin Cameron. Braamfontein: Ravan Press, 1994. 264-68.

Kraak, Gerald. Ice in the Lungs. Johannesburg: Jacana Media, 2006.

Martens, Jeremy. "Citizenship, 'civilisation' and the creation of South Africa's Immorality Act, 1927." South African Historical Journal 59.1 (2007): 223-41. 
Mda, Zakes. The Madonna of Excelsior. Cape Town: OUP, 2002.

Moodie, T. Dunbar. "Black migrant mine labourers and the vicissitudes of male desire." Changing Men in Southern Africa. Ed. Robert Morrell. Pietermaritzburg: U of Natal P, 2001. 297-315.

Nkoli, Simon. "Wardrobes: Coming out as a black gay activist in South Africa." Defiant Desire: Gay and Lesbian Lives in South Africa. Ed. Mark Gevisser and Edwin Cameron. Braamfontein: Ravan Press, 1994. 249-57.

Nuttall, Sarah. "Subjectivities of whiteness." African Studies Review 44.2 (2001): 115-40.

Paton, Alan. Too Late the Phalarope. 1955. Middlesex: Penguin Books, 1983.

Posel, Deborah. "Race as common sense: Racial classification in twentieth-century South Africa." African Studies Review 44.2 (2001): 87-113.

Raditlhalo, Tlhalo Sam. "Senses of identity in A Chain of Voices and The Madonna of Excelsior." Journal of Literary Studies 27.4 (2011): 103-22.

Ratele, Kopano. "Sexuality as constitutive of whiteness in South Africa." NORA - Nordic Journal of Feminist and Gender Research 17.3 (2009): 158-74.

.Apartheid, anti-apartheid and post-apartheid sexualities." The Prize and the Price: Shaping Sexualities in South Africa. Ed. Melissa Steyn and Mikki van Zyl. Pretoria: HSRC Press, 2009. 290-306.

Reddy, Vasu. "Negotiating gay masculinities." Agenda 37 (1998): 65-70.

Retief, Glen. "Keeping Sodom out of the laager: The policing of sexual minorities in South Africa." Defiant Desire: Gay and Lesbian Lives in South Africa. Ed. Mark Gevisser and Edwin Cameron. Braamfontein: Ravan Press, 1994. 99-111.

Rich, Adrienne. "Compulsory heterosexuality and lesbian existence." Signs 5.4 (1980): 631-60.

Stokes, Mason. The Color of Sex: Whiteness, Heterosexuality, and the Fictions of White Supremacy. Durham: Duke U P, 2001.

Swart, Sandra. "'Man, gun and horse': Hard right Afrikaner masculine identity in post-apartheid South Africa." Changing Men in Southern Africa. Ed. Robert Morrell. Pietermaritzburg: U of Natal P, 2001. 75-89.

Toms, Ivan. "Ivan Toms is a fairy?: The South African Defence Force, the End Conscription Campaign and me." Defiant Desire: Gay and Lesbian Lives in South Africa. Ed. Mark Gevisser and Edwin Cameron. Braamfontein: Ravan Press, 1994. 258-63.

Warner, Michael. "Introduction: Fear of a Queer Planet." Social Text 29 (1991): 3-17.

Zulu, N. S. "The collective voice in The Madonna of Excelsior: Narrating transformative possibilities." Literator 27.7 (2006): 107-26. 